\title{
PERTANGGUNGJAWABANPT. POS INDONESIA (PERSERO) TERHADAP KETIDAKSESUAIAN LAYANAN POS EXPRESS DITINJAU DARI UNDANG-UNDANG NOMOR 8 TAHUN 1999 TENTANG PERLINDUNGAN KONSUMEN
}

\author{
Yosa Cynthia Maharani \\ e-Mail: yosacynthiamaharani@gmail.com
}

\begin{abstract}
Abstrak
Pos Express adalah salah satu layanan yang memiliki kualitas produk dan tariff bersaing dalam industry layanan perposan serta memiliki sifat dan jenis layanan dengan pelayanan khusus/special treatment. Dengan mengusung slogan yang diunggulkan, "kiriman Anda sehari sampai", PASTI!'.Pertanggungjawaban PT. Pos Indonesia (Persero) atas ketidaksesuain layanan Pos Express adalah dengan memberi ganti rugi atas kerugian konsumen baik berupa keterlambatan, kerusakan maupun kehilangan kiriman.

Perlindungan hukum terhadap konsumen yang ditinjau dari Undang-Undang Nomor 8 Tahun 1999 tentang Perlindungan Konsumen, dilakukan PT. Pos Indonesia (Persero) melalui cara preventif dan represif. Penyelesaian komplain yang diajukan konsumen kepada PT. Pos Indonesia (Persero) selama ini diselesaikan melalui baik melalui jalur diluar pengadilan/jalurdamai dengan memberikan ganti rugi maupun melalui jalur pengadilan.
\end{abstract}

\section{Kata kunci: Pos Express dan Perlindungan Konsumen}

\section{Abstract}

Pos Express is one of the services possessing quality products and competitive tariffs in the postal service industry and also characteristics and types of services with special treatment. With the slogan "Kiriman Anda Sehari Sampai", PASTI, the accountability of PT Pos Indonesia (Persero) for any inappropriateness of services of Pos Express is to give compensation for consumers' loss either in the forms of delay, damage or loss.

The legal protection to the consumers from the Act no. 8 year 1999 on Consumer Protection, is conducted by PT. Pos Indonesia (Persero) through preventive and repressive modes. The settlement of complaints by the consumers to PT. Pos Indonesia (Persero) has been made through either out of court/peace path by giving compensation or court path.

Key words: Post express and consumers' protection 


\section{PENDAHULUAN}

Dalam dunia perposan di tanah air, nama besar PT. Pos Indonesia (Persero) telah lama dikenal oleh masyarakat Indonesia. PT. Pos Indonesia (Persero) merupakan sebuah Badan Usaha Milik Negara (BUMN) Indonesia yang bergerak dibidang layanan pos. Adapun layanan yang diberikan oleh PT. Pos Indonesia (Persero) dalam Pasal 1 Undang-Undang Nomor 38 Tahun 2009 tentang Pos dirumuskan bahwa pos adalah layanan komunikasi tertulis dan/atau surat elektronik, layanan paket, layanan logistik, layanan transaksi keuangan, dan layanan keagenan pos untuk kepentingan umum.

Berdasarkan Peraturan Pemerintah (PP) Nomor 15 Tahun 2013 tentang Pelaksanaan Undang-Undang Nomor 38 Tahun 2009 tentang Pos, dijelaskan bahwa pos adalah layanan komunikasi tertulis dan/atau surat elektronik, layanan paket, layanan logistik, layanan transaksi keuangan, dan layanan keagean pos untuk kepentingan umum (Pasal 1 Ayat 1). Mengutip dari Pasal 1 Ayat (1) penyelenggaraan pos merupakan perwujudan pos dari fungsi pengangkutan, yaitu memindahkan barang atau orang dari satu tempat ke tempat lainnya, dengan maksud untuk meningkatkan daya guna dan nilai antar bangsa. Oleh karena itu, dapat disimpulkan bahwa dibentuknya PT. Pos Indonesia (Persero) diarahkan untuk menunjang kebutuhan kepentingan umum dengan mempererat kerja sama dalam hubungan antar bangsa. ${ }^{1}$

${ }^{1}$ Kurnia Sarta Sitanggang, "Pelaksanaan Asuransi Terhadap Konsumen Pengguna Barang Dan Jasa Pos Dalam Pengiriman Surat Dan Paket Pos Domestik Oleh
Salah satu layanan dari PT. Pos Indonesia (Persero) yang bergerak dalam bidang pengiriman barang dan dokumen adalah Pos Express. Pos Express diposisikan sebagai salah satu layanan yang memiliki kualitas produk dan tariff bersaing dalam industri layanan perposan serta memiliki sifat dan jenis layanan dengan pelayanan khusus/special treatment. Dengan mengusung slogan yang diunggulkan, "kiriman Anda seharisampai", PASTI!'. Produk ini yang kini menjadi produk andalan dari PT. Pos Indonesia (Persero). ${ }^{2}$

Dari berbagai tantangan yang dihadapi, PT. Pos Indonesia (Persero) memiliki sisi lain yang dapat menjadi sebuah keunggulan jika dibandingkan dengan pesaingnya seperti TIKI, JNE, JNT, PAHALA Express yaitu adalah dari segi wilayah jangkauan layanannya, segi keberadaan lokasinya, dan keterjangkauan harga pengirimannya. Kini PT. Pos Indonesia (Persero) telah mampu menunjukkan kreatifitasnya dalam pengembangan bidang perposan di Indonesia dengan memanfaatkan insfrastruktur jejaring yang dimilikinya yang saat ini mencapai hingga sekitar 24.000 titik layanan yang menjangkau 100 persen kota/kabupaten, hampir 100 persen kecamatan dan 42 persen kelurahan/desa, dan 940 lokasi transmigrasi terpencil, sehingga terdapat jumlah total 4.006 Kantor Pos yang ditambah dengan adanya 1.811 mobil pos yang sudah dilengkapi

PT. Pos Indonesia (Persero) Pusat Daerah Istimewa Yogyakarta" (Skripsi Sarjana, Fak. Hukum Univ. Gajah Mada, Yogyakarta, 2014), hlm. 3

2 Lihat Anonim, "Pos Express"dalam http://www.posindonesia.co.id/index.php/pos-express/, diaksespadatgl. 07 Juni 2017 
dengan teknologi secara online sehingga satu sama lainnya terhubung secara real time. ${ }^{3}$

Adanya sebuah kewajiban untuk memberikan pelayanan yang baik sesuai dengan mutu standar yang telah ditetapkan merupakan salahsatu upaya untuk melindungi konsumennya. Kewajiban pemberian perlindungan terhadap konsumennya, telah disebutkan dalam Undang-undang Nomor 38 Tahun 2009 tentang Pos. Namun, kita sering mendapat kesan atau pengalaman negatif bahwa mengirim surat dengan pos itu "tidak terjamin", dalam arti "bisa diterima bisa pula tidak". Apalagi jika kita mengirim atau menerima barang atau paket". ${ }^{4}$

Resiko diatas tidak saja disebabkan dari pihak pos sendiri melainkan juga dari pihak konsumen. Dengan adanya isi perjanjian, PT. Pos Indonesia (Persero) menggunakan ketentuan/syarat pengiriman Pos Express yang tertuang dalam point yang terdapat pada resi/tanda bukti pengiriman (consigment note), yang sudah mendapat kata sepakat/persetujuan dari para pihak (PT Pos dan konsumen), maka timbullah perikatan bagi keduanya yaitu adanya hak dan kewajiban masing-masing pihak.

Dalam perjanjian yang terjadi antara pengirim dengan PT. Pos Indonesia (Persero) tidak selamanya sesuai dengan yang dikehendaki oleh para pihak. Sering terjadi bahwa salah satu pihak merasa dirugikan dalam perjanjian itu. Demikian halnya dengan perjanjian antara pengirim

\begin{tabular}{l}
\hline LihatAnonim, "Berita Tentang Pos" \\
dalamhttp://www.postel.go.id/berita_tentang_pos, \\
diaksespadatgl. 07 Juni 2017 \\
4 Lihat KK Raharjo. "Pak Pos Yang Jujur", dalam \\
Kompas, 06 Desember 2017, hlm. 7
\end{tabular}

dengan PT. Pos Indonesia (Persero), dimana PT. Pos Indonesia (Persero) tidak melaksanakan atau memenuhi kewajibannya dalam perjanjian sehingga terjadi wanprestasi. Bentuk-bentuk wanprestasi antara lain adalah surat dan paket pos terlambat, rusak, atau hilang. ${ }^{5}$

Menyadari akan hal ini dan pentingnya profesionalitas perusahaan yang bergerak dalam bidang jasa dalam menindak lanjuti/mengatasi complain konsumen yang masuk, penulis tertarik untuk memilih kajian tentang "Pertanggungjawaban PT. Pos Indonesia (Persero) terhadap ketidaksesuaian layanan Pos Express ditinjau dari Undang-undang Nomor 8 Tahun 1999 tentang Perlindungan Konsumen" dengan metode hukum empiris dengan menggunakan pendekatan yuridis sosiologis, yang hendak mengkaji pelaksanaan Undang-Undang Nomor 8 Tahun 1999 tentang Perlindungan Konsumen.

\section{PEMBAHASAN}

\section{A. Pertanggungjawaban PT. Pos Indonesia (Persero) terhadap Ketidaksesuaian}

\section{Layanan Pos Express}

Meskipun telah mengandalkan berbagai macam teknologi informasi, masih saja ada beberapa konsumen yang merasa dikecewakan

${ }^{5}$ Deni Eka Putra, "Perlindungan Hukum Terhadap Pengguna Jasa Pengiriman Surat dan Barang pada PT. Pos Indonesia (Persero) Cabang Padang" (Skripsi Sarjana, Fak. Hukum Univ. Andalas, Padang, 2011), hlm. 5 
atas pelayanan yang diberikan sehingga kemudian mengajukan komplain kepada pihak PT. Pos Indonesia (Persero) sebagai perusahaan penyedia layanan/jasa. Disinilah PT. Pos dituntut untuk dapat bersikap profesional dalam menangani komplain. Komplain yang diajukan pengguna jasa Pos Express secara garis besar dapat digolongkan menjadi tiga yaitu, keterlambatan pengiriman, kerusakan dan kehilangan.

Seperti pada umumnya perusahaan yang memiliki petunjuk pelaksanaan (juklak) atau petunjuk teknis (juknis) dalam menangani permasalahan perusahaan, PT. Pos Indonesia (Persero) juga melaksanakan pertanggungjawabnnya berdasarkan Sistem
Operasional Prosedur (SOP). Sistem ini dirancang untuk mempermudah pegawai dalam melakukan tugasnya sehari-hari dan juga dalam kaitannya menangani komplain konsumen.

\section{Prosedur pengajuan komplain konsumen Pos Express}

1a

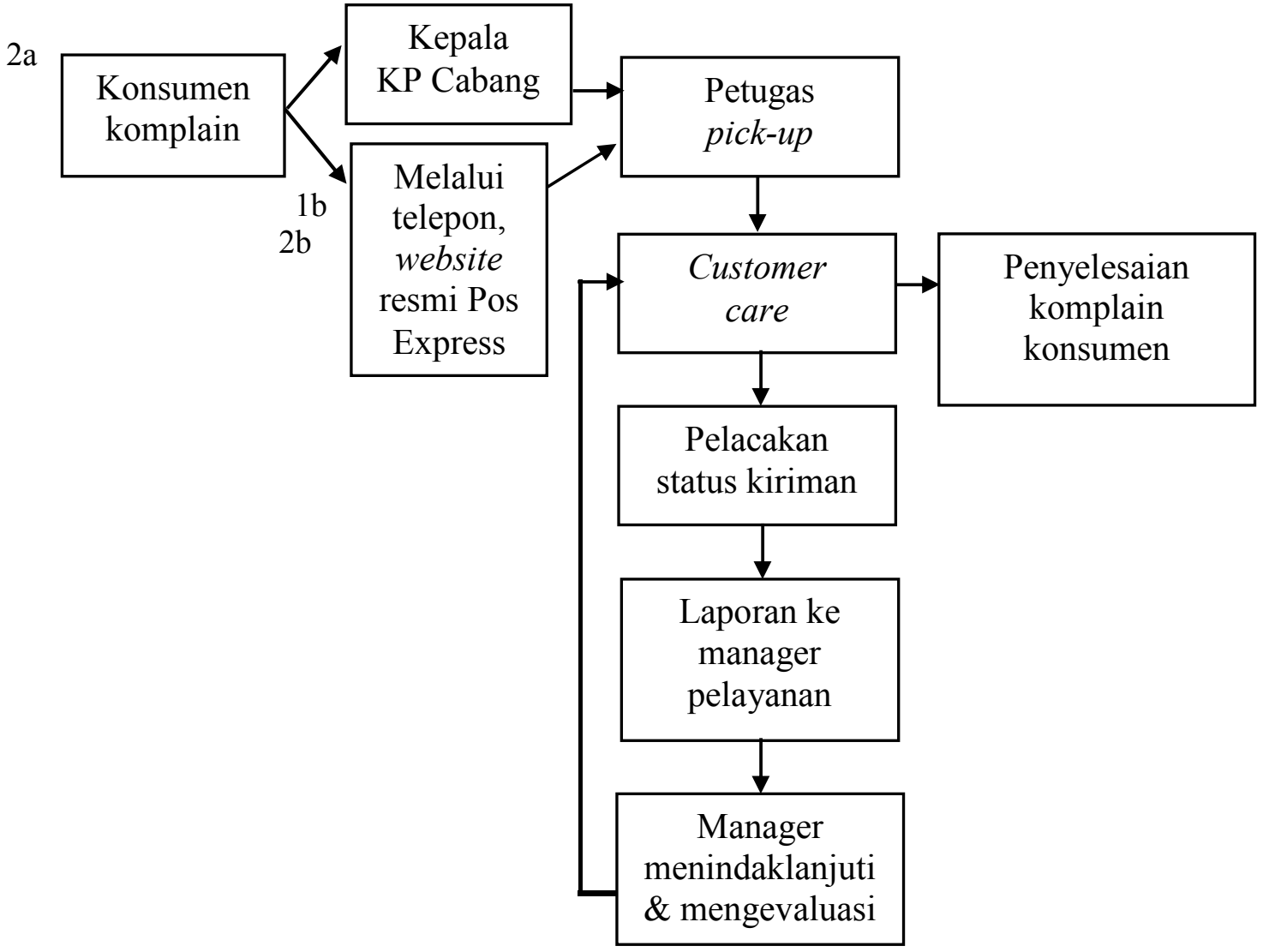


Konsumen dapat mengajukan komplain mereka melalui beberapa cara, yaitu melalui Kepala Kantor Pos Cabang (KPC), melalui nomor telepon customer care maupun melalui website resmi PT. Pos Indonesia (Persero). Laporan atas keterlambatan, kerusakan, ataupun kehilangan ini kemudian ditangani oleh petugas customer care dan dilaporkan pada manager pelayanan untuk dianalisis. Selanjutnya, konsumen akan menerima tanggapan atas komplain yang diajukan dari petugas customer care. Konsumen diinformasikan hasil jejak lacak dan status pengiriman.

Tangung jawab PT. Pos Indonesia (Persero) dalam memberikan ganti rugi sudah diatur dalam Keputusan Direksi PT. Pos Indonesia (Persero) Nomor: KD.65/DIRUT/0812 tentang jaminan ganti rugi surat dan paket dalam negeri dan Keputusan Direksi Nomor: KD.43/DIRRATKET/0216 tentang jaminan ganti rugi kiriman internasional express mail service (EMS), paket internasional dan surat tercatat internasional. ${ }^{6}$

Pasal 28 Undang-Undang Nomor 38 Tahun 2009 tentang Pos juga merumuskan bahwa:

"Pengguna layanan pos berhak mendapatkan ganti rugi apabila terjadi:

a. Kehilangan kiriman

b. Kerusakan isi paket

c. Keterlambatan kiriman; atau

d. Ketidaksesuaian antara barang yang dikirim dan yang diterima."

Pasal 1365 Kitab Undang-Undang Hukum Perdata menentukan bahwa
"Tiap perbuatan melanggar hukum, yang menimbulkan kerugian pada orang lain, mewajibkan orang yang karena salahnya menerbitkan kerugian, mengganti kerugian tersebut."

Kesimpulan dari pasal itu adalah setiap orang yang dirugikan oleh peristiwa/kelalaian, kurang hati-hati, berhak mendapatkan ganti rugi (kompensasi) atas kerugiannya itu, tetapi untuk mendapatkan hak ganti rugi tersebut Undangundang membebankan permbuktian kesalahan orang lain dalam peristiwa tersebut kepada mereka yang menggugat ganti rugi. ${ }^{7}$

Besar ganti rugi yang diberikan berbedabeda berdasarkan jenis keluhan yang diajukan oleh pelanggan. Untuk komplain atas keterlambatan, PT. Pos Indonesia (Persero) memberikan ganti rugi sebesar 1x (satu kali) ongkos kirim, untuk komplain atas kerusakan/kehilangan barang, PT Pos Indonesia (Persero) memberikan ganti rugi sebesar nilai barang yang didasarkan Harga Tanggungan Ongkos Kirim (HTOK), yaitu maksimal 10x (sepuluh kali) ongkos kirim. Sedangkan berdasarkan Harga Tanggungan Nilai Barang (HTNB) maksimal pemberian ganti rugi yang akan diberikan oleh PT. Pos Indonesia (Persero) adalah sebesar harga pertanggungan nilai barang, berdasarkan HTOK dan HTNB maksimal adalah 10 (sepuluh) kali ongkos pengiriman barang dari nilai barang yang dipertanggungkan.

\footnotetext{
${ }^{7}$ Nasution, Konsumen Dan Hukum (Jakarta, 1995),
} hlm. 171 


\section{Proses pelaksanaan pertanggungjawaban PT Pos Indonesia terhadap ketidaksesuaian}

layanan Pos Express

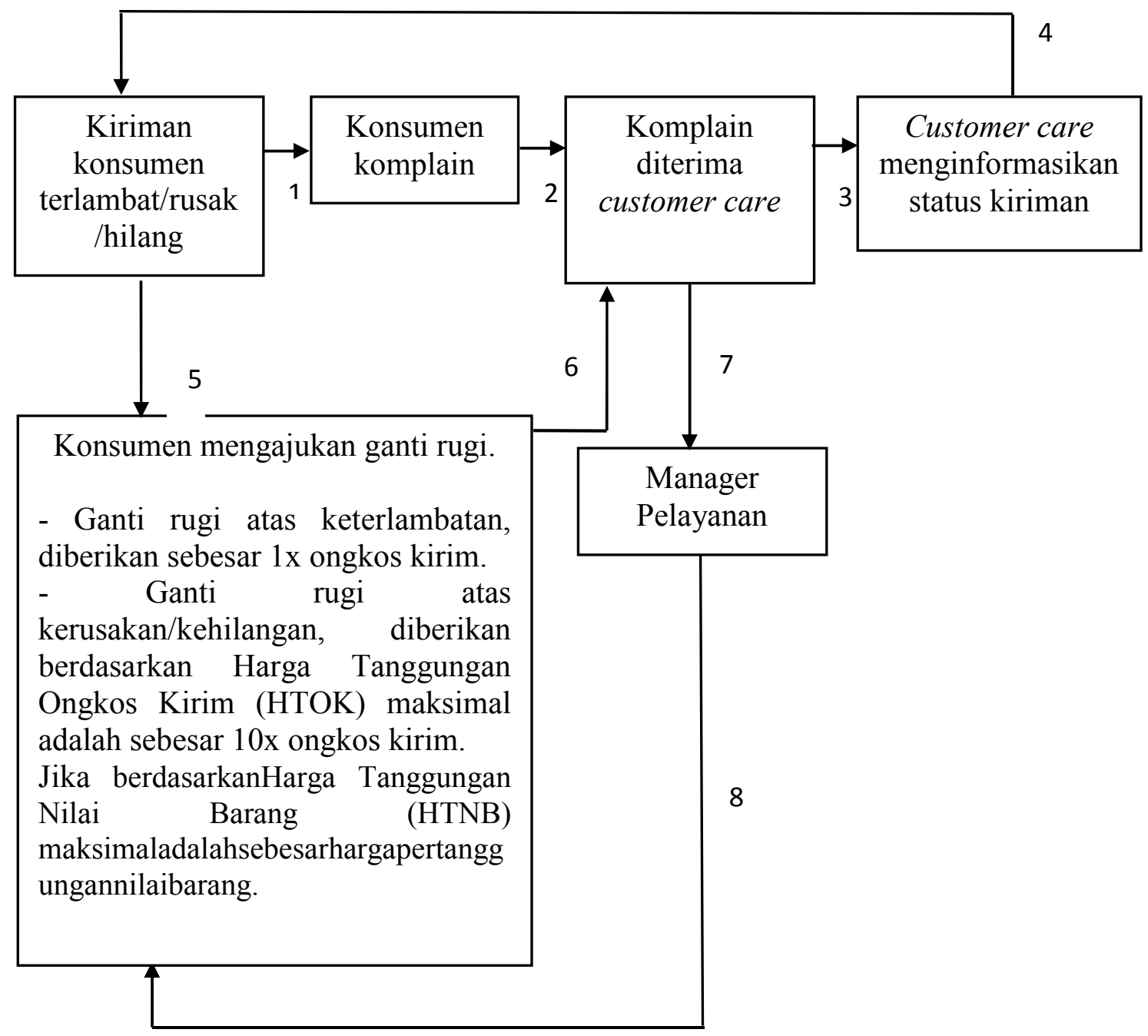

Dari skema diatas, dapat dilihat bahwa setelah konsumen mendapati barang kirimannya mengalami keterlambatan, kehilangan ataupun kerusakan, langkah pertama yang harus konsumen lakukan adalah melaporkan komplain atas kerugian yang dideritanya pada PT. Pos Indonesia (Persero), hal ini sesuai dengan apa yang tercantum dalam empat hak dasar Kennedy, yaitu hak untuk didengarkan (right to be heard) yang menyatakan bahwa konsumen memiliki hak untuk didengar kan kebutuhan dan klaim, karena hak ini terkait dengan hak untuk memperoleh informasi. ${ }^{8}$

Tanggung jawab produsen yang dikenal dengan wanprestasi adalah tanngung jawab berdasarkan kontrak. Dengan demikian ketika

\footnotetext{
${ }^{8}$ Lihat hak-hak konsumen, "Hak-Hak Konsumen" dalam miraayu-mira.blogspot.co.id2011/03/hak-hakkonsumen.html, diakses tgl. 02 Januari 2018
} 
suatu produk rusak dan mengakibatkan kerugian konsumen, biasanya pertama-tama melihat isi kontrak baik tertulis maupun lisan ${ }^{9} \mathrm{Di}$ dalam melakukan pengajuan tuntutan ganti rugi kepada PT. Pos Indonesia (Persero), maka konsumen harus memiliki resi (bukti terima kiriman). Resi merupakan tanda bukti terima kiriman. Selain itu, di dalam ketentuan dan syarat-syarat pengiriman tersebut dijelaskan bahwa PT. Pos Indonesia (Persero) bertanggungjawab terhadap kiriman yang dikirim apabila pengirim telah membayar lunas semua biaya pengiriman dan biaya lainnya dan memiliki bukti terima kiriman asli (bukan fotocopy).

\section{B. Perlindungan Hukum terhadap}

Konsumen Pengguna JasaPos Express

Dilihat dari Undang-UndangNomor 8 Tahun 1999 tentang Perlindungan

\section{Konsumen}

Konsumen Pos Express adalah orang yang menggunakan jasa Pos Express, baik ritel (pelanggan individu/perorangan) ataupun corporate untuk mengirimkan surat atau barang ke tujuan tertentu. Konsumen pengguna jasa Pos Express yang dimaksudkan dalam penelitian ini adalah kedua konsumen tersebut, pelanggan korporat dan pelanggan ritel.

Perlindungan hukum memiliki 2 (dua) makna yaitu perlindungan hukum bersifat preventif dan represif. Perlindungan preventif adalah perlindungan untuk mencegah terjadinya sengketa di kemudian hari atau kepada rakyat

9 Abdul Halim Barakatullah, Hukum Perlindungan Konsumen Kajian Teoritis Dan Perkembangan Pemikiran (Bandung, 2008), hlm. 61 diberikan kesempatan untuk mengajukan keberatan atau pendapat sebelum keputusan pemerintah mendapatkan bentuk definitif sehingga degan demikian perlindungan preventif bertujuan untuk mencegah sebelum ada terjadinya sengketa. Dan perlindungan represif adalah perlindungan setelah terjadi sengketa yang bertujuan untuk memulihkan hak-hak dari pihak yang dirugikan. ${ }^{10}$

1. Perlindungan hukum preventif

Dalam perusahaan pengiriman barang, keadaan yang tidak diinginkan ini adalah terjadinya keterlambatan, kehilangan dan kerusakan barang, khususnya kerugian pada pihak konsumen. Tindakan preventif perlu untuk diterapkan mengingat penyelesaian sengketa relatif sulit, memerlukan waktu yang lama dalam penyelesaiannya dan tidak jarang memerlukan biaya yang tinggi. Tindakan preventif tersebut dapat berupa penjelasan mengenai kontrak pengiriman barang (terdapat pada resi pengiriman) agar terdapat suatu keseimbangan antara pelaku usaha dan konsumen.

Upaya lainnya, saat ini PT. Pos Indonesia sedang melaksanakan program modernization and empowerment. Program tersebut mengandung antara lain pembenahan business model, peningkatan brand image (corporate identity) PT. Pos Indonesia, perubahan divisi regional sebagai profit centre, infrastruktur bisnis berbasis ICT (information communication technology). Pengguna jasa pada PT. Pos Indonesia adalah masyarakat umum dari semua kalangan yang ingin

10 Philipus M. Hadjon, Perindungan Hukum Bagi Rakyat Indonesia (Jakarta, 1987), hlm. 15 
melakukan pengiriman barang/surat dengan menggunakan pos. Sedangkan untuk mempertahankan konsumen PT. Pos Indonesia terus berusaha lebih meningkatkan fasilitas dan pelayanan serta kepercayaan para pelanggan. ${ }^{11}$

Bentuk kenyamanan yang diberikan oleh PT. Pos Indonesia (Persero) kepada konsumen yaitu dalam memberikan pelayanan dimana pihak pos menerapkan ketepatan, kecepatan dalam proses pengiriman barang, misalnya dengan memperluas loket layanan, agar konsumen tidak lama mengantri dalam proses pengiriman surat/barang.

Bentuk keamanan yang diberikan PT. Pos Indonesia (Persero) dalam pengiriman paket (khususnya), barang yang akan dikirim harus dilakukan control check oleh petugas (petugas berhak membuka isi kiriman). Kegunaan control check ini untuk memastikan apakah barang tersebut layak dikirimkan atau tidak. Petugas juga berhak meminta kejelasan alamat penerima dan pengirim serta contact person masing-masing pihak. Untuk kemanan selanjutnya, barang kiriman akan dilakukan pemilahan/sortir di bagian processing dimana barang akan dipisahkan berdasarkan jenis barang. Apakah paket tersebut masuk ke dalam paket Express atau paket dangerous goods. Dan akan dipilah berdasarkan kota tujuan. Pihak PT. Pos Indonesia (Persero) juga memberikan pengikat kantong berupa tali seal, segel dan logo fragile untuk barang dangerous goods pada setiap barang yang telah dikemas. Hal ini

11 Syaidah, "Persepsi Masyarakatatas Pemanfaatan TIK pada Layanan Pos di Kantor Pos Cianjur" Jurnal Penelitian Pos dan Informatika-BPPKI, Volume IV, No. 2/2004, hlm. 138 bertujuan untuk memberikan keamanan terhadap barang kiriman.

Bentuk keselamatan terhadap barang kiriman yang diberikan oleh PT. Pos Indonesia (Persero) berupa pengawasan yang dilakukan petugas sortir, dimana dilakukan pengecekan barang kiriman agar barang masuk sesuai kantong masing-masing tujuan dan tidak tertukar satu sama lain.

Konsumen Pos Express berhak mendapatkan kenyamanan, keamanan dan keselamatan dalam mempergunakan produk dan jasa para pelaku usaha. Hal ini dimaksudkan untuk menjamin agar nantinya para konsumen terhindar dari kerugian fisik maupun psikis. Dengan demikian, setiap produk baik dari segi kualitas dan kuantitas, harus diarahkan untuk mempertinggi rasa kenyamanan, keamanan dan keselamatan konsumen. ${ }^{12}$

Adapun upaya pelaksanaan perlindungan hukum untuk konsumen yang dilakukan oleh PT. Pos Indonesia (Persero) telah mengikuti aturan Undang-Undang Perlindungan Konsumen yang berlaku, dimana PT. Pos Indonesia (Persero) tetap melihat hak-hak konsumen yang harus dilindungi. Jika dikaitkan dengan Pasal 4 Undang-Undang Perlindungan Konsumen tentang hak-hak konsumen yakni:

a. Hak atas kenyamanan, keamanan, dan keselamatan dalam mengkonsumsi barang dan/jasa.

b. Hak memilih barang dan/jasa serta mendapatkan barang dan atau/jasa tersebut

12 Deni Indriyani, "Perlindungan Hukum Terhadap Konsumen Akibat kelalaian Pengiriman Barang Oleh PT. Pos Indonesia (Persero) Kantor Pemeriksa (KPRK) Padang" (Skripsi Sarjana, Fak. Hukum Univ. BungHatta, Padang, 2016), hlm. 7 
dengan nilai tukar dan kondisi dan jaminan yang dijanjikan.

c. Hak atas informasi yang benar, jelas dan jujur mengenai kondisi dan jaminan barang dan/jasa.

d. Hak untuk didengar pendapat dan gugatannya atas barang dan/jasa yang digunakan.

e. Hak untuk mendapatkan advokasi, perlindungan, dan upaya penyelesaian sengketa perlindungan konsumen serta patut.

f. Hak untuk mendapat pembinaan dan pendidikan konsumen.

g. Hak untuk diperlakukan atau dilayani secara benar dan serta tidak diskriminatif.

h. Hak untuk mendapatkan kompensasi, ganti rugi dan/atau penggantian apabila barang dan/jasa yang diterima tidak sesuai dengan perjanjian atau sebagaimana mestinya.

i. Hak-hak yang diatur dengan dalam ketentuan peraturan perundang-undangan lainnya.

PT. Pos Indonesia (Persero) telah memenuhi ketentuan Pasal 4 Undang-Undang Perlindungan Konsumen huruf (c), bahwa PT. Pos Indonesia (Persero) memberikan informasi kepada konsumen tentang ketentuan dan syaratsyarat pengiriman Pos Express pada halaman belakang bukti pengiriman pos. Konsumen juga dapat melihat jenis-jenis layanan dan tarif kiriman Pos Express pada poster yang ditempel di setiap kantor pos atau pada situs resmi pos (www.posindonesia.co.id) maupun dapat dilihat pada aplikasi Ongkir Pos Indonesia, Tarif Kiriman Pos Indonesia (yang bisa di download pada aplikasi playstore maupun appstore).

Jadi, Pasal 4 huruf (c) yang memuat tentang hak konsumen atas pemberian informasi yang benar dan jujur telah dipenuhi oleh PT. Pos Indonesia (Persero). Selain memberikan informasi, pihak PT. Pos Indonesia (Persero) juga berusaha melayani konsumen tanpa membedakan pengguna jasanya. Semua konsumen, baik korporat maupun ritel mendapat pelayanan sama. Hal ini membuktikan bahwa Pasal 4 huruf (g) tentang hak konsumen untuk dilayani dengan benar dan tanpa diskriminatif telah dipenuhi oleh PT .Pos Indonesia (Persero).

Walaupun komplain konsumen Pos Express dari tahun ke tahun semakin meningkat, tetapi semuanya telah diselesaikan dengan baik dan tuntas. PT. Pos Indonesia (Persero) juga akan memberikan ganti rugi jika terbukti. Jadi Pasal 4 huruf (d) dan (h) telah dilaksanakan oleh PT Pos. Indonesia (Persero).

Sebagai pelaku usaha, PT. Pos Indonesia (Persero) selain mempunyai hak, juga mempunyai kewajiban dan tanggung jawab kepada konsumennya. Undang-Undang Perlindangan Konsumen Pasal 7 mengatur kewajiban pelaku usaha, yaitu:

a. Beritikad baik dalam melakukan kegiatan usahanya.

b. Memberikan informasi yang benar, jelas dan jujur mengenai kondisi dan jaminan barang dan/jasa serta memberi penjelasan penggunaan, perbaikan, dan pemeliharaan.

c. Memperlakukan atau melayani konsumen secara benar dan jujur serta tidak diskriminatif.

d. Menjamin mutu barang dan/jasa yang diproduksi dan/atau diperdagangkan berdasarkan ketentuan standart mutu barang dan/jasa yang berlaku.

e. Memberi kesempatan kepada konsumen untuk menguji, dan/atau mencoba barang dan/jasa tertentu serta tidak memberi jaminan dan/atau garansi atas barang yang dibuat dan/atau yang diperdagangkan.

f. Memberi kompensasi, ganti rugi dan/atau penggantian atas kerugian akibat penggunaan, pemakaian, dan pemanfaatan barang dan/jasa yang diperdagangkan.

g. Memberi kompensasi, ganti rugi dan/atau penggantian apabila barang dan/jasa yang diterima atau dimanfaatkan tidak sesuai dengan perjanjian. 
PT Pos Indonesia (Persero) memberikan informasi kepada konsumen tentang ketentuan dan syarat-syarat pengiriman Pos Express pada halaman belakang bukti pengiriman pos (dapat dilihat pada lampiran).

Sistem Operasional Prosedur (SOP) dapat pula dibaca oleh konsumen di belakang bukti kirim yang dapat memberikan informasi yang dibutuhkan konsumen atau konsumen dapat bertanya langsung kepada petugas pos. Jadi, Pasal 7 huruf (b) tentang kewajiban pelaku usaha untuk memberikan informasi yang benar dan jujur telah dipenuhi oleh PT. Pos Indonesia (Persero).

PT. Pos Indonesia (Persero) melayani komplain konsumen tanpa membedakan siapa konsumennya. Semua komplain yang diterima berusaha dilayanani dengan baik, baik itu pelanggan ritel maupun korporat. Kenyataan ini telah sesuai dengan Pasal 7 huruf (c) UndangUndang Perlindungan Konsumen tentang kewajiban pelaku usaha melayani konsumen dengan jujur, jelas, benar dan tanpa diskriminatif telah dipenuhi.

2. Perlindungan hukum represif

Tindakan hukum represif digunakan apabila telah terjadi sengketa antara pelaku usaha dengan konsumen. Menurut Undang-
Undang Nomor 8 Tahun 1999 Tentang Perlindungan Konsumen salah satu hak konsumen adalah mendapatkan advokasi, perlindungan dan tindakan penyelesaian sengketa secara patut sebagaimana dimaksud dalam Pasal 4 huruf e Undang-Undang Nomor 8 tahun 1999 Tentang Perlindungan Konsumen. Selain itu, salah satu kewajiban pelaku usaha adalah memberikan kompensasi, ganti rugi dan/atau penggantian atas kerugian akibat penggunaan, pemakaian, dan pemanfaatan barang dan/atau jasa yang diperdagangkan sebagaimana diatur dalam Pasal 7 huruf $\mathrm{f}$ Undang-Undang Nomor 8 tahun 1999 Tentang Perlindungan Konsumen.

Perlindungan hukum yang selama ini ada pada PT. Pos Indonesia (Persero) lebih mengarahkan pada perlindungan hukum represif. Kecenderungan perlindungan hukum yang represif ini karena sengketa dengan konsumen telah membawa pengaruh buruk bagi citra perusahaan sehingga harus segera diselesaikan dengan baik. Sementara ketentuan upaya perlindungan hukum yang represif dapat dilihat pada Pasal 45 ayat (2) Undang-Undang Nomor 8 Tahun 1999 tentang Pos. Selain itu dapat juga dilihat pada Pasal 13 ayat (1) perjanjian kerjasama dengan corporate. 


\section{Perlindungan Hukum Konsumen Jasa Pos Express}

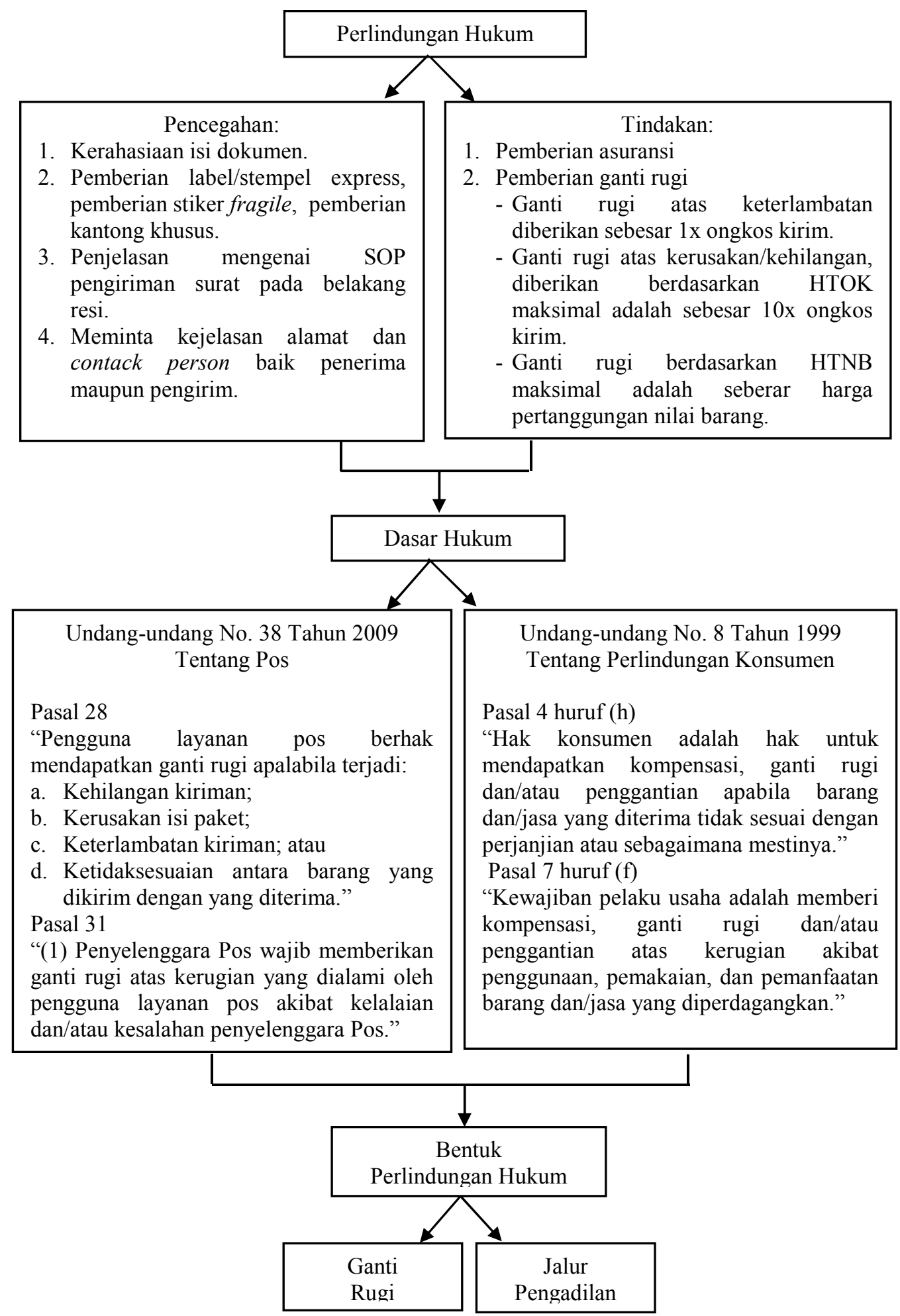




\section{PENUTUP}

Berdasarkan uraian yang terdapat dalam analisis hasil di atas, maka dapat diperoleh beberapa kesimpulan sebagai berikut:

1. Pertanggungjawaban PT. Pos Indonesia (Persero) atas ketidaksesuain layanan Pos Express adalah dengan memberi ganti rugi atas kerugian konsumen baik berupa keterlambatan, kerusakan maupun kehilangan kiriman. Ketentuan ganti rugi yang diberlakukan telah sesuai dengan sistem operasional prosedur. Ganti rugi mengenai keterlambatan diberikan sebesar satu kali ongkos kirim dan ganti rugi mengenai kehilangan/kerusakan sebesar harga tanggungan nilai barang (HTNB) atau maksimal sepuluh kali harga tanggungan ongkos kirim (HTOK).

2. Perlindungan hukum terhadap konsumen yang ditinjau dari Undang-Undang Nomor 8 Tahun 1999 tentang Perlindungan Konsumen, dilakukan PT Pos Indonesia (Persero) melalui cara preventif dan represif. Pemberian hak konsumen dan kewajiban PT. Pos Indonesia (Persero) sebagai pelaku usaha sudah sesuai Undang-Undang Perlindungan Kosumen. Penyelesaian komplain yang diajukan konsumen kepada PT. Pos Indonesia (Persero) selama ini diselesaikan baik melalui jalur diluar pengadilan/jalur damai dengan memberikan ganti rugi maupun melalui jalur pengadilan.

\section{DAFTAR PUSTAKA}

\section{Buku-buku:}

Atmadjaja, Djoko Imbawani. 2012. Hukum Dagang Indonesia. Malang: Setara Press

Barakatullah, Abdul Halim. 2008. Hukum Perlindungan Konsumen Kajian Teoritis Dan Perkembangan Pemikiran. Bandung: Nusa Media

Fajar,Mukhtie. 2001.Tipe Negara Hukum. Malang: Banyu Media

Gunawan. 2001.Hukum Perlindungan Konsumen Indonesia. Jakarta: Gramedia Pustaka Utama

Hadjon, Philipus M. 1987. Perindungan Hukum Bagi Rakyat Indonesia. Jakarta: PT Bina Ilmu

Kristianti, Celina Tri Siwi. 2011. Hukum Perlindungan Konsumen. Jakarta: Sinar Grafika

Miru, Ahmad \&Yodo, Sutarman. 2010. Hukum Perlindungan Konsumen. Jakarta: Rajawali Pers

Nasution. 1995. Konsumen Dan Hukum. Jakarta: Pustaka Sinar Harapan

Santoso,Lukman. 2012. Hukum Perjanjian Kontrak. Yogyakarta: Setara Press

Siahaan, N. H. T. 2005. Hukum Konsumen. Jakarta: Samitra Media Utama

Sidabalok' Janus. 2006.Hukum Perlindungan Konsumen di Indonesia. Medan: PT Citra Aditya Bakti

Sidharta, 2000. Hukum Perlindungan Konsumen Indonesia. Jakarta: PT Gramedia Widiasarana Indonesia Grasindo

Sofie, Yusuf. 2003. Perlindungan Konsumen dan Instrumen-instrumen Hukumnya. Bandung: Citra Aditya Bakti

Yani, Ahmad \&Widjaja, Gunawan. 2003. Seri Hukum Perseroan Terbatas. Jakarta: Rajawali Pres 
Makalah, Orasi, Jurnal, dan Laporan Penelitian:

Indriyani, Deni. 2016. "Perlindungan Hukum Terhadap Konsumen Akibat kelalaian Pengiriman Barang Oleh PT. Pos Indonesia (Persero) Kantor Pemeriksa (KPRK) Padang”. Skripsi. Padang: Univ. BungHatta

Putra, Deni Eka. 2011. "Perlindungan Hukum Terhadap Pengguna Jasa Pengiriman Surat dan Barang pada PT. Pos Indonesia (Persero) Cabang Padang". Skripsi. Padang: Univ. Andalas

Rindani, Liantika Rizky. 2016 "Perlindungan Konsumen Jasa Pos Menurut Undangundang Nomor 8 Tahun 1999 Dan Hukum Islam (Studi Di PT. Pos Indonesia (Persero) Merjosari Malang". Skripsi. Malang : UIN Maliki

Sitanggang, Kurnia Sarta. 2014. "Pelaksanaan Asuransi Terhadap Konsumen Pengguna Barang Dan Jasa Pos Dalam Pengiriman Surat Dan Paket Pos Domestik Oleh PT. Pos Indonesia (Persero) Pusat Daerah Istimewa Yogyakarta". Skripsi. Yogyakarta: UGM

Syaidah. 2004. "Persepsi Masyarakatatas Pemanfaatan TIK pada Layanan Pos di Kantor Pos Cianjur" dalam Jurnal Penelitian Pos dan Informatika-BPPKI, Volume IV, No. 2/2004

Yudikindra, Widyananda. 2016. "Perlindungan Hukum Bagi Pelaku Usaha Jasa Pengiriman Paket Barang Domestik Atas Tindakan Konsumen Yang
Beritikad Tidak Baik (Studi Pada PT. Pos Indonesia (Persero) Yogyakarta)" dalam Jurnal Law Reform FH-Undip, Volume XII, No. 1/2016

\section{Koran, Internet:}

Anonim. 2017. "Berita Tentang Pos" dalam http://www.postel.go.id/berita_tentang pos, diaksestgl. 07 Juni 2017

Anonim. 2017. "Pos Express" dalam http://www.posindonesia.co.id/index.ph p/pos-express/, diaksestgl. 07 Juni 2017

Ayu, Mira. 2018. "Hak-Hak Konsumen” dalam miraayumira.blogspot.co.id2011/03/hak-hakkonsumen.html, diakses tgl. 02 Januari 2018

Raharjo, KK. 2017. "Pak Pos Yang Jujur", dalam Kompas, 06 Desember 2017

\section{Peraturandan Perundang-undangan}

Kitab Undang-Undang Hukum Dagang

Kitab Undang-Undang Hukum Perdata

Peraturan Pemerintah Republik Indonesia No. 15 Tahun 2013 tentang Penyelenggaraan Pos

Undang-Undang No. 8 Tahun 1999 tentang Perlindungan Konsumen

Undang-Undang No. 38 Tahun 2009 tentang Pos. 